\title{
Analysis of the Affecting Factors of China's Direct Investment in Countries along "The Belt and Road"
}

\author{
Liangchao Huang \\ School of Management Engineering, Zhengzhou University, Zhengzhou 450001, China \\ Corresponding Author:95010370@qq.com
}

Keywords: Countries along “The Belt and Road”, Foreign Direct Investment, Affecting factor, Regression analysis

\begin{abstract}
This paper selects the data of China's direct investment and its influencing factors in 63 countries along “The Belt and Road” from 2005 to 2016. Through the establishment of an empirical analysis model, the five selected factors and foreign direct investment were analyzed by regression analysis, and the impact of various factors on China's foreign direct investment was studied. Finally, based on the empirical research conclusions, it proposes policy recommendations to promote China's foreign direct investment, such as adjusting investment scope, optimizing industrial structure, making full use of foreign exchange reserves and strengthening technological innovation under the background of "Belt and Road.
\end{abstract}

\section{Introduction}

In recent years, China's exchanges with foreign countries have become more and more frequent, and the scale of the "going out" strategy has continued to expand. China's foreign direct investment is in a period of rapid development. With the appearance of "The Belt and Road", China's economic and trade exchanges with different countries and regions along the route have been further deepened. The scale of the two-way investment and trade has been continuously improved, and the field of economic and trade cooperation has been broadened. At the same time, China's direct investment in the countries along the "Belt and Road" has developed rapidly, which makes China become another gathering area for foreign direct investment outside Asia. China is facing a good opportunity for foreign investment, but it also faces host country's investment risks. Compared with European and American countries, the development of China's foreign investment still has some shortcomings. By studying the factors affecting foreign direct investment, enterprises can be guided to make full use of the huge domestic foreign exchange reserves for overseas investment and to avoid trade protectionist barriers. At the same time, it can provide certain guidance to the government's policy formulation which helps the government formulate more favorable policies. Therefore, it is of practical significance to study the influencing factors of direct investment in countries along the "Belt and Road", carrying out capacity cooperation and optimizing investment models. 


\section{Literature review}

\subsection{Foreign Research Review}

According to the Investment Development Cycle theory proposed by John.H.Dunning, As the level of economic development continues to increase, the scale and form of foreign direct investment in investment countries will also change, which means that a country's foreign investment will be affected by the country's levels of economic development(Dunning J H,2009). On the basis of Dunning's theory, Rosfadzimi Mat Saad determined the factors of OFDI in Malaysia. Multivariate regression analysis was carried out on the time series data from 1981 to 2011. The study found that productivity level, export level affected the direct foreign investment of home country (Saad R M, 2014). Andreff described the emergence of new multinational companies and then provided an econometric test of the relationship between foreign direct investment and economic levels. Research has shown that developing countries' economic development level has a positive impact on their foreign direct investment (Andreff $\mathrm{W}$, 2002). Lipsey R E proposed that there is a substitutional relations between trade and investment. He believes that foreign direct investment development will replace the country's exports, and the two are negatively correlated, when one is rising, the other is falling. (Blomstrom M, 2000). Kojima Kiyoshi proposed that trade and investment are complementary. He believes that foreign direct investment development will promote the country's export trade, which is a positive correlation (Kojima K, 1973). X Zhang and $\mathrm{K}$ Daly quantified the main drives of China's foreign direct investment through panel data analysis from 2003 to 2009, including bilateral and multilateral trade, market size, GDP growth, openness and resource endowments (Zhang X, 2016). Using annual data from 1979 to 2000, O'Meara G uses the Johansen cointegration test to study the role of foreign investment in promoting economic growth through exports. The results show gross domestic product, FDI and exports have a longterm relationship (O'Meara G, 2017). Mijiyawa, Abdoul' Ganiou used five years of panel data and systematic GMM technology from 1970 to 2009 to empirically analyze the factors driving foreign direct investment in Africa, and believe countries that are more open, politically stable and provide higher returns on investment will attract more foreign direct investment (Mijiyawa,2016).Through empirical research on Swedish multinational companies, Braconier found that the more developed foreign direct investment flows to the country, the more intensive R\&D resources, the more obvious the reverse technology spillover effect(Braconier H,2001).

\subsection{Domestic Research Review}

Kaiwen Ji, Ji Zhou selected the panel data of 52 countries along "The Belt and Road” in China from 2003 to 2014, and established a stochastic frontal gravitation model for empirical analysis. It was concluded that foreign direct investment is positively correlated with the host country's economic situation, political stability, labor force and other factors (Kaiwen Ji, 2018). Bin Xiong and Mengjiao Wang used the data of direct investment of 48 countries along "The Belt and Road " in 2005-2015 to build a spatial panel model to empirically test the third-country effects and influencing factors of China's foreign direct investment in the countries along the route, confirming the host country market scale. The scale, foreign exchange reserves, export levels, and labor costs have had a significant impact on China's foreign direct investment (Bin Xiong, 2018). Liangpei Lin, based on the comparative perspectives of different types of countries in the host country, empirically test that China's direct investment in countries along "The Belt and Road" has a significant positive relationship with host country market size, resource endowment and foreign direct investment levels (Liangpei Lin, 2017). Zhonghai Cheng and Nan Nan used the panel data of 54 countries in "The Belt and Road" from 2005 to 2014. The SFA model used the calculation and 
analysis to show that China's foreign direct investment is positively correlated with the economic development status and export level of the host country (Zhonghai Cheng, 2018). Based on the multinational panel data of the countries along the Belt and Road Initiative from 2003 to 2014, Zhanqi Yao used the stochastic frontier gravitational model to study the influencing factors of China's foreign direct investment reverse technology spillover. Studies have shown that the technological innovation level of the host countries along "The Belt and Road" has a significant positive impact on China's foreign direct investment reverse technology spillover(Zhanqi Yao,2017) . Wanbo Lu, Yongrui Chang, Yetao Wang 's independent innovation capability and total factor productivity model of the investment country have tested the model of China's foreign direct investment to promote technology spillover(Wanbo Lu,2017).

Fenli Zou believes that there are two main factors affecting foreign direct investment of a country's enterprises. One is the driving factor of the investor country itself, that is the internal factor; the other is the pulling factor of the host country, that is the external factor (Fenli Zou,2017). In summary, most scholars focus on the factors affecting foreign investment in the host country, while less scholars pay attention to the factors affecting foreign investment in the home country, so this paper mainly studies the internal impact of foreign direct investment factors. At the same time, most scholars consider the influencing factors to consider whether foreign investment promotes technology spillovers and reverse spillovers, while fewer scholars pay attention to the influence of home country's technological innovation capabilities on foreign direct investment. Therefore, considering the impact mechanism of foreign direct investment and the availability of sample data, we finally selected the five factors of economic development level, export level, foreign exchange reserve level, foreign direct investment level and technological innovation level. I believe that the level of economic development The three factors of foreign exchange reserve level and technological innovation level are more important.

\section{Analysis of China's Direct Investment in Countries along "The Belt and Road"}

\subsection{The Scale of Foreign Investment Continues to Expand}

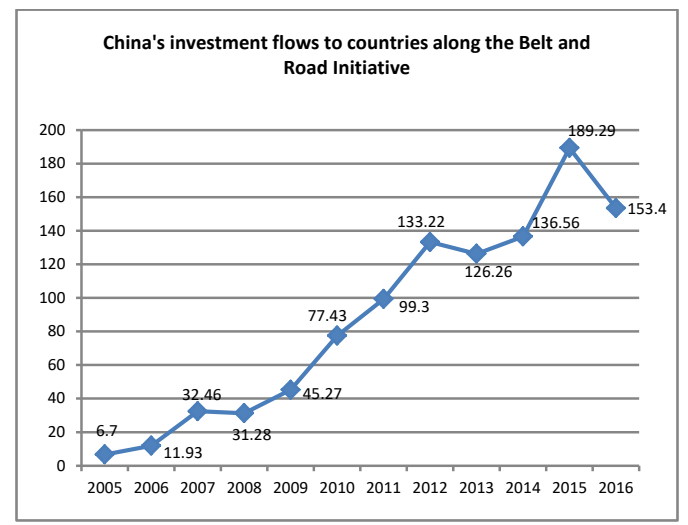

Source: 2005-2016 China Foreign Direct Investment Bulletin

Figure 1 China's direct investment flows to countries along “The Belt and Road” in 2005-2016 (Unit: US\$100 million)

Relevant departments of the Chinese government have released China's foreign investment data since 2003. For more than a decade, the scale of foreign investment has maintained rapid growth, jumping from the 26th in the world in 2002 to the second place in 2016. China's direct investment in "The Belt and Road" countries has developed rapidly in 2005-2016 (see Figure 1). In 2005, China's direct investment in countries along “The Belt and Road” was only 670 million US dollars. 
The overall investment rate has developed rapidly. In 2015, China's investment in "The Belt and Road” countries reached a record high of US\$18.929 billion, equivalent to 28 times that of 2005. However, compared with the proportion of China's total foreign investment in the countries along “The Belt and Road " (see Figure 2), China's investment rate along "The Belt and Road " countries is still low, and the countries along "The Belt and Road" still have huge investment potential.



Source: 2005-2016 China Foreign Direct Investment Bulletin

Figure 2 Countries along “The Belt and Road” account for China's total foreign investment ratio in 2005-2016

\subsection{The Investment Cooperation among "The Belt and Road" Countries is Steadily Promoted}

Table 1 Regional distribution of China's foreign direct investment stock in 2017

\begin{tabular}{|c|c|c|c|}
\hline area & $\begin{array}{c}\text { Amount (100 million US } \\
\text { dollars) }\end{array}$ & Year on year & proportion \\
\hline Asia & 9094.5 & $67 \%$ & $67 \%$ \\
\hline Africa & 398.8 & $2.9 \%$ & $2.9 \%$ \\
\hline Europe & 872 & $6.4 \%$ & $6.4 \%$ \\
\hline Latin America & 2071.5 & $15.3 \%$ & $15.3 \%$ \\
\hline North America & 754.7 & $5.6 \%$ & $2.8 \%$ \\
\hline Oceania & 382.4 & $2.8 \%$ & $100.0 \%$ \\
\hline total & 13573.9 & $100.0 \%$ & \\
\hline
\end{tabular}

Source: 2017 China Foreign Direct Investment Bulletin

As of the end of 2016, China's foreign investment is distributed in 190 countries (regions). In recent years, Chinese companies' investment cooperation with countries along "The Belt and Road" has become a new bright spot. Throughout 2017, Chinese companies have increased investment in 59 countries along “The Belt and Road", totaling US\$14.36 billion, accounting for $12 \%$ of the total for the same period, an increase of 3.5 percentage points over the same period last year. The contract value of newly signed foreign contracted projects in 61 countries along "The Belt and Road” was US\$144.32 billion, accounting for 54.4\% of the total period, up $14.5 \%$ year-on-year; the turnover was 85.53 billion US dollars, accounting for $50.7 \%$ of the total period, an increase of $12.6 \%$.

\subsection{M\&A Actively Exists in Concentrated Foreign Investment Industry}

China's investment in the countries along "The Belt and Road” focuses on energy, metals and transportation, and the tertiary industry has an obvious upward trend. The concentration of the industry is high, the products are diversified, and the characteristics of industrial upgrading are 
obvious. In 2016, China's enterprises implemented a total of 765 M\&A projects, distributed in 74 countries and regions around the world, with a total transaction volume of 135.33 billion US dollars; direct investment of 86.5 billion US dollars, accounting for 63.9\%, and overseas financing of 48.83 billion US dollars, accounting for 36.1\%. . Among them, Chinese companies have 115 M\&A projects along “The Belt and Road”, with a M\&A amount of US\$6.64 billion, accounting for 4.9\% of the total M\&A. Among them, Malaysia, Cambodia, the Czech Republic and other countries have attracted more than US\$500 million in Chinese M\&A investment.

\section{An Empirical Analysis of the Affecting Factors of China's Direct Investment in Countries along the "Belt and Road"}

\subsection{Selection of Variables and Its Expected Results}

According to the above, the selected factors mainly include: the economic development level, foreign exchange reserves, export quota, foreign direct investment and technological innovation level of the investing country. This paper uses the regression analysis method to test these five variables.

Table 2 Model variable table

\begin{tabular}{|c|c|c|}
\hline variable & Indicator name & variable name \\
\hline Explained variable & Foreign direct investment level & ODI \\
\hline \multirow{2}{*}{ Explanatory variables } & economic development level & GDP \\
\cline { 2 - 3 } & Foreign exchange reserve level & FER \\
\hline Explanatory variables & Export level & EX \\
\hline & Foreign direct investment level & FDI \\
\hline & Technological innovation level & TIL \\
\hline
\end{tabular}

According to the theoretical analysis of the impact of the previous influence, we assume that domestic GDP will promote foreign direct investment. Exports are promoting rather than inhibiting in China. The increase in foreign exchange reserves will promote the development of foreign direct investment and attract more foreign capital inflows. It will also promote China's overseas investment, and foreign direct investment will increase with the improvement of technological innovation.

\subsection{Sources of Data}

When selecting the sample interval, taking into account the data availability of the factors affecting OFDI, and in order to ensure the scientificity of the empirical analysis results, this paper selects the data from 2005-2016 for regression analysis. In each test and regression process, the variables are selected by logarithmic formation to alleviate the heteroscedasticity problem in the model regression process. Therefore, the regression coefficient is elasticity: every $1 \%$ change of the independent variable value will bring about the change of the dependent variable value. ODI is derived from the China Foreign Direct Investment Bulletin. FER is from the website of the State Administration of Foreign Exchange. GDP, EX and FDI are sourced from the website of the National Bureau of Statistics (China Statistical Yearbook 2017). TIL is measured by the amount of domestic R\&D expenditures, also from the National Bureau of Statistics website.

\subsection{Model Setting}

In this paper, the relationship between ODI, GDP, EX, FER and TIL time series data is 
empirically analyzed by multiple linear regression analysis. The general model form of multiple linear regression analysis is: $y=\alpha+\beta_{i} x_{i}+\mu$.

Where $y$ represents the explanatory variable, $x_{i}$ is the explanatory variable, and $\beta_{i}$ is the coefficient of the explanatory variable, $\mu$ is a random error.

Through the above discussion, the variables selected in this section include ODI, GDP, EX, FDI and FER. Combined with the form of multiple linear regression models, the following model equations are established:

$L n O D I=\alpha+\beta_{1} L n G D P+\beta_{2} L n F D I+\beta_{3} L n F E R+\beta_{4} L n E X+\beta_{5} L n T I L+\mu \quad$ Where, $\mu$ is the error term. Logarithmic processing of variables can eliminate data non-stationary and heteroscedasticity. The coefficients $\beta_{1}, \beta_{2}, \beta_{3} \beta_{4}$ in the model represent the elasticity of ODI to their respective variables. Specifically, $\beta_{1}$ represents the elasticity of ODI to China's economic development level; $\beta_{2}$ represents the elasticity of ODI to foreign direct investment level FDI; $\beta_{3}$ represents the elasticity of ODI to foreign exchange reserve level FER; $\beta_{4}$ represents the elasticity of ODI to export level EX, $\beta_{5}$ represents ODI technology Innovation level TIL flexibility.

\subsection{Establishment and Analysis of Model}

Modeling: import the data into MINITAB software and select the command "Statistics > Regression > Regression > Fit Regression Model”. The results are shown in Table 3.

Table 3 Regression analysis: ODI, GDP, FER, EX, FDI and TIL

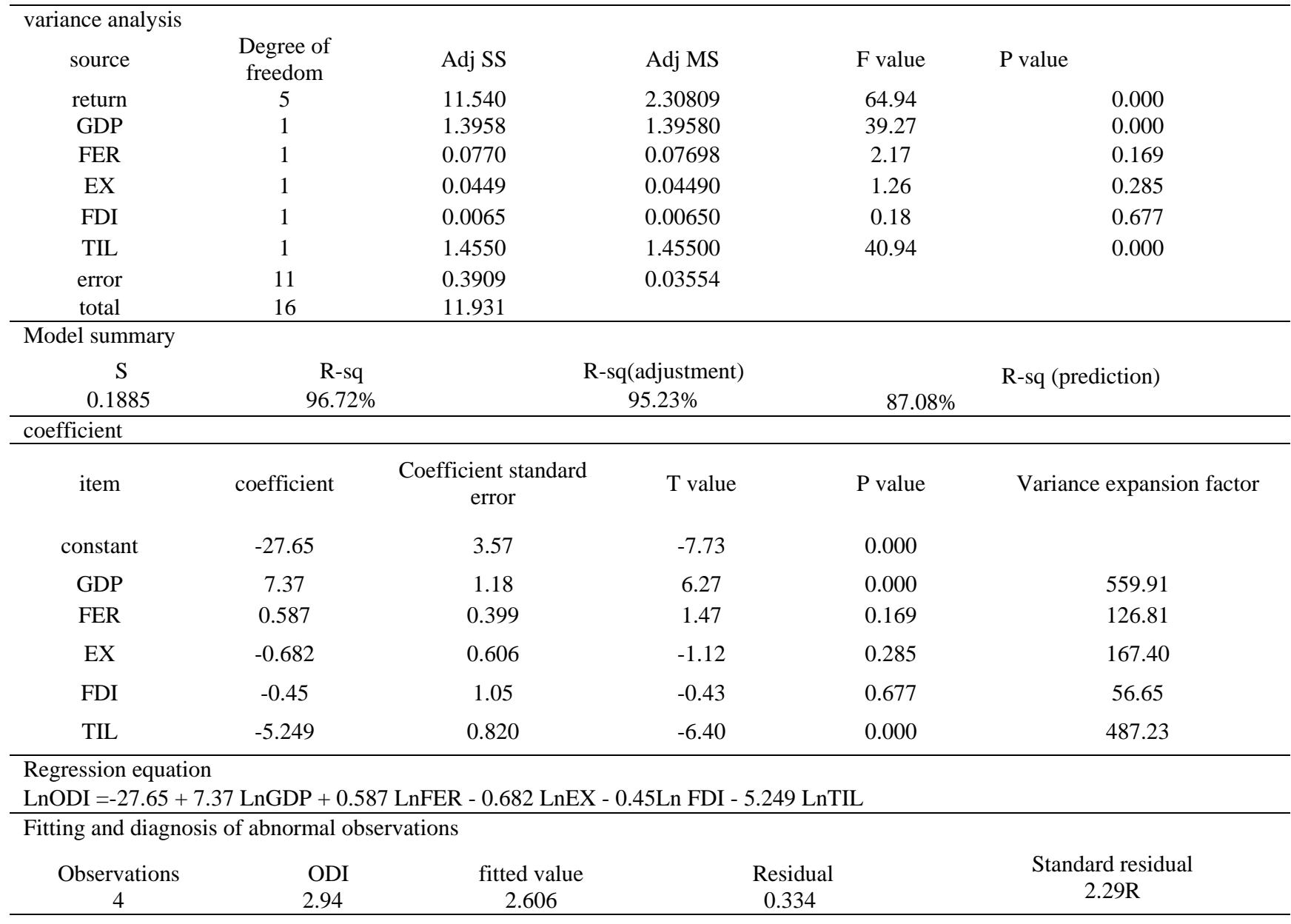


Interpretation of the output:

(1) Analysis of the total significance test results of the regression equation from the ANOVA table, since the $\mathrm{P}$ value $=0<\alpha=0.05$, indicating that the total effect of the linear regression equation is significant at the significance level $\alpha=0.05$.

(2) Metrics of regression model significance: From the perspective of $R-S q=96.72 \%$ $R-S q($ adjustment $)=95.23 \%$, the two are very close, and $\mathrm{S}=0.18852$, the model fitting effect is good.

(3) Significant test for each regression coefficient: from the regression coefficient, the $p$ values of the independent variables GDP, FER, and TIL are all less than $\alpha=0.05$, so these three factors are significant factors; and the independent variables EX, FDI If the p value is greater than $\alpha=0.05$, the effect is not significant, so when modifying the model, the independent variables EX and FDI should be deleted first.

(4) Residual analysis: First check the four-in-one residual map (see Figure 3).

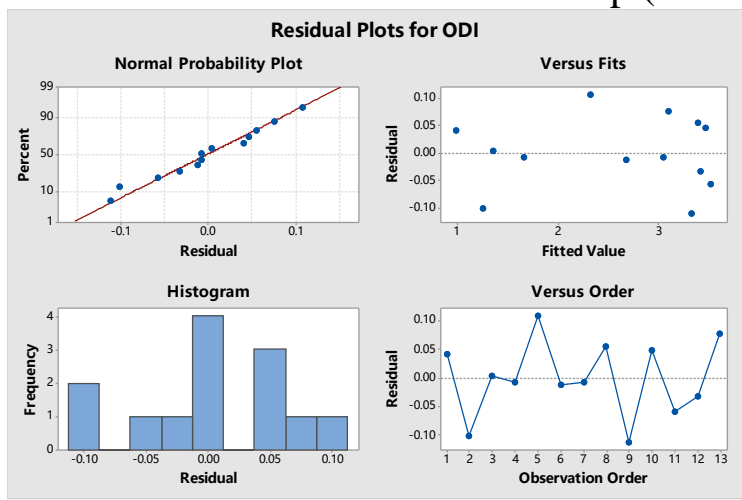

Figure 3 Four-in-one residual map

1) Residual and data sequence diagram (lower right corner in Figure 3), this diagram is normal, and the residuals are randomly distributed in order of observations.

2) Residual and fitted value map (upper right corner in Figure 3), this figure is normal, no flare shape distribution is seen, indicating that the linear model is acceptable.

3) The normal probability map of the residual (upper left corner in Figure 3), this graph is normal. The data is basically on a straight line, and the residual is considered to be normally distributed. The histogram of the residual (lower left corner in Figure 3) also shows the normality of the residual.

\subsection{Adjustment and Analysis of Model}

Delete the independent variable EX, FDI, and only retain the independent variables GDP, FER, and TIL, and the regression calculation is performed again. Select the command "Statistics > Regression > Regression > Fitting Regression Model". The results are shown in Table 4.

Interpretation of the output of the model after correction:

(1) From the significance test results of the regression equation (ANOVA output table), p value $=0<\alpha=0.05$, indicating that the total effect of the regression equation is significant at the significance level $\alpha=0.05$.

(2) From the regression coefficient test output, the p values of the independent variables GDP, FER, and TIL are all less than $\alpha=0.05$, so all factors are significant factors.

(3) The coefficient of determination $\mathrm{R}-\mathrm{Sq}=96.30 \%$, indicating that the independent variable can explain $96.30 \%$ of the variation in the response variable, and the correction coefficient R-Sq (adjustment) $=95.45 \%$, which is closer to R-Sq (originally $\mathrm{R}-\mathrm{Sq}=96.72 \%$, R-Sq (adjustment) $=$ 
95.23\%,), which is the result of eliminating the independent variables EX and FDI (although the value of R-Sq is slightly decreased).

(4) The interpretation of the residual map output after the model correction is the same as before, and all the maps are normal. See the four-in-one residual plot (Figure 4).

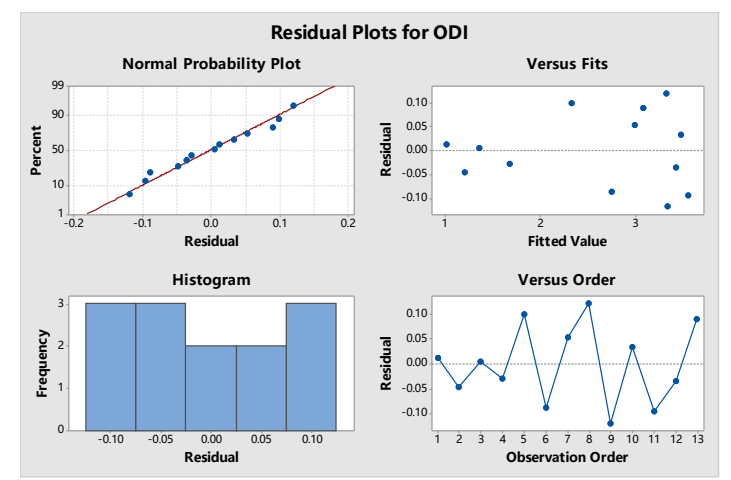

Figure 4 Four-in-one residual map

Table 4 regression analysis: ODI, GDP, FER, and TIL

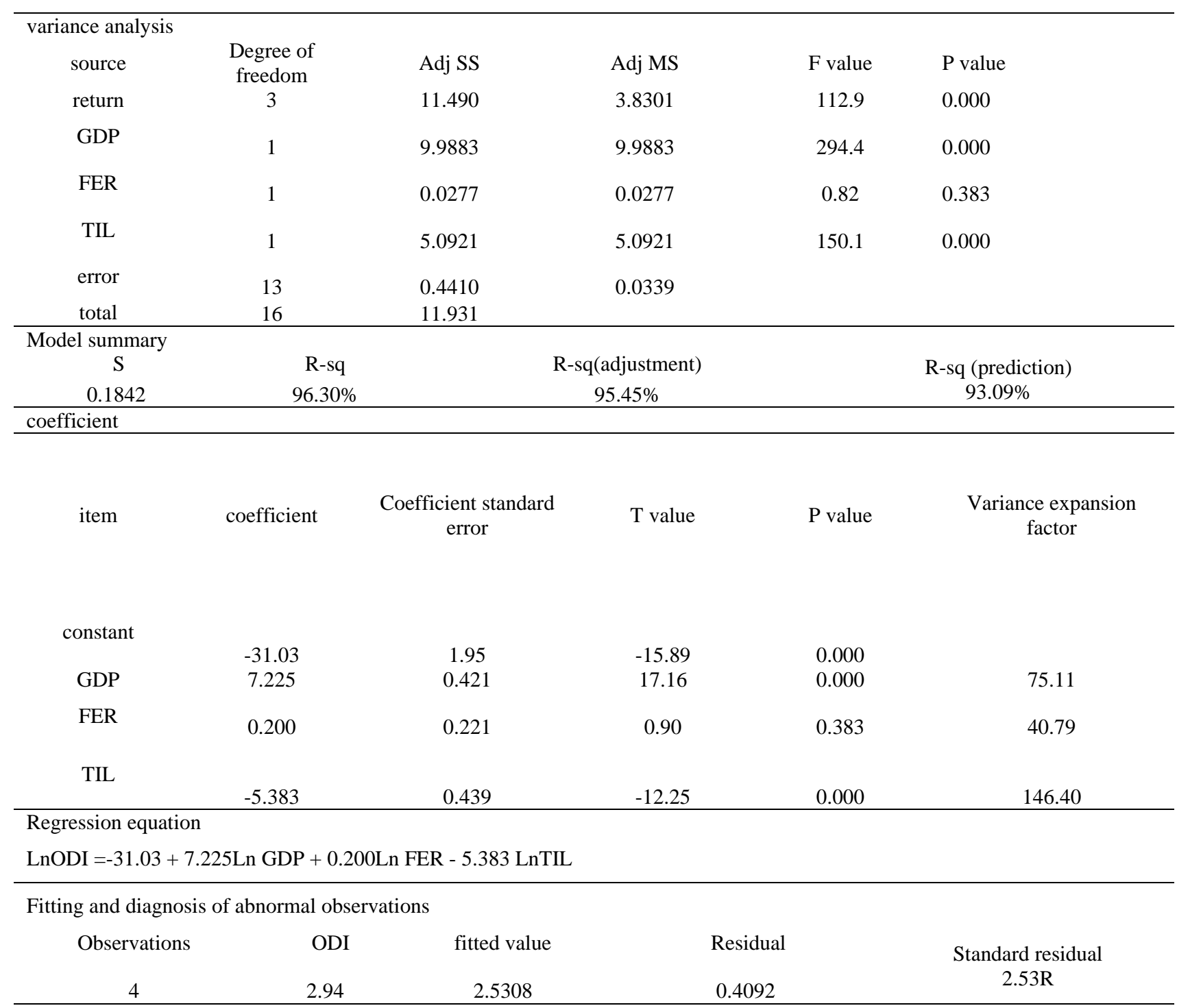


According to the goodness of fit coefficient $R^{2}=0.9630$, the degree of fitting of the model is good, and the level of economic development, foreign exchange reserve level, coefficient of technological innovation level and coefficient of constant term of China is higher. It can explain the factors affecting China's foreign direct investment in China's foreign direct investment by $96.30 \%$.

According to the empirical analysis process of the above regression results, it can be seen that the level of economic development, the level of foreign exchange reserves, and the level of technological innovation are the main factors affecting foreign direct investment, while other factors are not obvious.

\section{Conclusion and countermeasures}

This paper takes China's direct investment in the countries along "The Belt and Road " as the research object, and proposes five factors that have a greater impact on direct investment, and uses China's 2005-2016 data on direct investment and its influencing factors along "The Belt and Road " countries for empirical analysis. The empirical results show that China's GDP and foreign exchange reserves have a positive effect on China's direct investment in countries along "The Belt and Road", and the level of economic development is the strongest force supporting foreign direct investment activities. Financial support was provided for foreign direct investment. However, the regression analysis found that the level of technological innovation is negatively correlated with China's direct investment impact on countries along "The Belt and Road". This is inconsistent with expectations. The possible explanation is that due to the limited data, the sample size is too small to accurately reflect the impact of technological innovation on China's foreign direct investment. At the same time, part of China's foreign direct investment aims to learn the technology of the host country, which has created a reverse technology spillover effect.

According to the above analysis of the status quo and empirical analysis and its implications, foreign direct investment is the "advanced team" of China's "Belt and Road" international development strategy. To achieve this strategic goal, it is necessary to further adjust the investment scope and GDP, vigorously carry out technological innovation. Therefore, this paper proposes the following countermeasures:

\subsection{Optimize the Geographical Scope of Foreign Direct Investment}

According to the previous article on the status quo and existing problems of China's direct overseas investment in China, China's direct investment along "The Belt and Road" is mainly concentrated in the Asian region. The investment is concentrated in Singapore, Russia, Kazakhstan, Indonesia and other countries. The limited amount of direct investment in West Asia and Central and Eastern European countries is not conducive to the long-term development of OFDI (Wuqi Zhou, 2015). Our company should start from a global perspective, not just limited to a country's tax policy. It can focus on Eastern European countries and some developing countries, this is a big market. Enterprises should open their horizons of investment and focus on these areas.

\subsection{Accelerate the Optimization and Upgrading of Industrial Structure and Improve the Quality of Economic Development}

The optimization and upgrading of industrial structure is the important way to further increase GDP. Increasing GDP level depends on the reconstruction and upgrading of existing industrial structure. Through international capacity cooperation with countries along "The Belt and Road ", we can promote the improvement of domestic enterprises' technical level and product quality, promote China's industrial transformation and upgrading, and adjust economic structure, and realize 
a leap from product export to industrial output, thus making China's Capacity utilization has improved(Yongchao Song,2018). In order to change the small proportion of China's foreign direct investment in manufacturing, the state should deregulate, encourage enterprises with high energy consumption to transfer investment, and transfer to the low-industry domestic central and western regions and industrial regions downstream of industrial gradients, so that traditional enterprise capital Get recycled. In order to change the dilemma that some industries are already at zero marginal revenue, the state should adjust industrial structure policies, encourage technological innovation, promote the optimization and upgrading of Chinese industries, and increase the added value of products.

\subsection{Make Full Use of Foreign Exchange Reserves}

China's world's largest stock of foreign exchange reserves is largely the result of China's trade surplus. According to the previous empirical analysis, it is known that foreign exchange reserves are positively related to a country's foreign direct investment. Therefore, the Chinese government should encourage enterprises to make overseas direct investment, which can not only make full use of foreign exchange reserves, but also a policy to resolve trade surplus. Foreign exchange reserves used to purchase foreign debt may face risks such as high risks and yields. It is better to encourage enterprises to make foreign direct investment. Not only can they learn advanced foreign technology and knowledge, but they can also avoid the risk of external debt to a certain extent. In view of the fact that China's overseas investment enterprises are mainly state-owned enterprises and there are few private enterprises, our government should encourage private enterprises to enable more private enterprises to invest overseas and make full use of China's foreign exchange reserves.

\subsection{Strengthen Technological Innovation and Enhance Foreign Investment}

Chinese enterprises should make full use of foreign direct investment reverse technology spillovers to enhance China's technological innovation capability, the key is to improve the digestion and absorption capacity of the home country (Xianfeng Han, 2018). On the one hand, the government needs to increase the investment of human resources in China, especially in the central and western regions, and improve the absorption capacity of various regions in China; on the other hand, it should implement differentiated foreign investment strategies according to the different technological absorptive capacities of different regions and expand Technology spillovers caused by foreign investment. In addition, increasing $R \& D$ investment is the key to improving China's technological innovation capability. The government can guide enterprises to increase $R \& D$ investment through appropriate policies, and adopt measures such as tax incentives and subsidies to increase the enthusiasm of R\&D investment.

\section{References}

[1] Andreff W, 2002. The new multinational corporations from transition countries[J]. Economic Systems, 26(4):371379.

[2] Blomstrom M, Konan D E, Lipsey R E, 2000 .FDI in the Restructuring of the Japanese Economy[J]. Social Science Electronic Publishing.

[3] Braconier H, Ekholm K, Knarvik K H M, 2001. In search of FDI-transmitted R\&D spillovers: A study based on Swedish data [J]. Weltwirtschaftliches Archiv, 137(4):644-665.

[4] Bin Xiong, Mengjiao Wang, 2018. Research on the Factors Affecting China's Direct Investment in the Countries along the Belt and Road Initiative Based on Spatial Perspective[J].International Trade Issues,2018(02):102-112.

[5] Dunning J H, 2009. Location and the Multinational Enterprise: A Neglected Factor?[J]. Journal of International Business Studies, 40(1):35-41.

[6] Fenli Zou, 2017. Empirical Analysis of Factors Affecting China's Foreign Direct Investment [D]. Jilin University of 
Finance and Economics.

[7] Kojima K, 1973. A Macroeconomic Approach to Foreign Direct Investment [J]. Hitotsubashi Journal of Economics, 14(1):1-21.

[8] Kaiwen Ji, Ji Zhou, 2018. The Efficiency of China's Foreign Direct Investment under the Construction of the Belt and Road Initiative and Its Influencing Factors_-Based on Stochastic Frontier Gravity Model [J].Journal of Economics and Management, 34(04):138-148.

[9] Liangpei Lin, etc, 2017. Analysis of the influencing factors of China's direct investment in "The Belt and Road" countries from a comparative perspective[J].Journal of Guangdong University of Finance and Economics,32(01):5762.

[10] Mijiyawa, Abdoul' Ganiou, 2016. What Drives Foreign Direct Investment in Africa? An Empirical Investigation with Panel Data [J]. African Development Review, 27(4):392-402.

[11] O'Meara G, 2017. Determinants of Foreign Direct Investment [J]. Ssrn Electronic Journal, 11(4):1.

[12] Rongzhen Yang, Qian Wei,2018. China's Direct Investment in Countries along the Belt and Road Initiative [J]. Price Theory and Practice, 2018(04): 114-117.

[13] Saad R M, Noor A H M, Nor A H S M, 2014. Developing Countries' Outward Investment: Push Factors for Malaysia $\approx[$ [J]. Procedia - Social and Behavioral Sciences, 130:237-246.

[14] Wanbo Lu, Yongrui Chang, Yetao Wang, 2015. China's Foreign Direct Investment, R\&D Technology Spillover and Technological Progress[J]. Research Management, 36(03): 38-48.

[15] Wuqi Zhou, 2015. Direct Investment Distribution and Challenge Response along "The Belt and Road" [J]. Reform, 2015(08): 39-47.

[16] Xianfeng Han, Ning Hui, etc, 2018. A new perspective on the improvement of spillover effect of OFDI reverse innovation — An empirical test based on environmental regulation[J].International Trade Issues,2018(04):103-116.

[17] Yongchao Song,2018. China's Foreign Direct Investment and International Capacity Cooperation under the "Belt and Road" Strategy [J]. Technology Economics and Management Research, 2018 (01): 86-90.

[18] Zhang X, Daly K, 2016. The determinants of China's outward foreign direct investment [J]. Emerging Markets Review, 12(4):389-398.

[19] Zhonghai Cheng, Nan Nan, 2018. The institutional environment of the host country under the framework of "The Belt and Road" and the potential of China's foreign direct investment [J]. Soft Science, 32 (01): 36-40.

[20] Zhanqi Yao, 2017. Research on the Factors Affecting China's OFDI Reverse Technology Spillover along "The Belt and Road" Countries [J].Journal of Beijing Technology and Business University, 32(05):11-24. 